\title{
Substance Use Among Adolescents, and Influencing Factors in Șanlıurfa
}

\section{Șanlıurfa Ilinde Adölesanlarda Madde Kullanma Durumu ve Etkileyen Faktörler}

\author{
Hülya Karataş1, Selma Kahraman2, Zeynep Marangoz3 \\ 1 Harran University Faculty of Health Science, Department of Pediatric Nursing, Sanliurfa, Turkey \\ 2 Harran University Faculty of Health Science, Department of Public Health Nursing, Şanlıurfa, Turkey \\ 3Şanlıurfa Public Health Offices, Şanlıurfa, Turkey
}

\section{ABSTRACT}

Aim: The aim of this study was to investigate substance use by students in the $7-12^{\text {th }}$ grades.

Materials and Methods: The research was conducted as a descriptive study in Şanlıurfa, which has a very young population, between September 2014 and March 2015. The research sample comprised 54.928 students in grades seven through twelve. The research data were obtained using a survey form prepared by the researchers according to the literature, and expert opinions were obtained from three specialists in the field before administering the survey. The data were evaluated using SPSS 17. Written permission from the relevant institutions and the verbal permission of the participants were obtained for conducting the study.

Results: Of the students, $51.6 \%$ were male, $23.8 \%$ were in ninth grade, $81.1 \%$ had 4 or more siblings, and $40.1 \%$ were the fourth or more in sibling order. While $23.2 \%$ were working when not at school; $6.3 \%$ smoked tobacco, $2.4 \%$ were using substances other than cigarettes, and $13.1 \%$ were acquainted with substance abusers. Those who said they used substances due to curiosity made up $31.3 \%$, and $29.9 \%$ said they used substances to feel more powerful. The smoking and substance use rate was higher for male students, working students, students with extremely domineering families and students exposed to domestic violence.

Conclusion: These data obtained on substance use by students and the factors that affect it suggest that studies should be carried out on substance use prevention, family awareness should be increased and prevention policies should be developed and implemented.

Keywords: Adolescents, addiction, substance use

\section{ÖZ}

Amaç: Bu çalışma 7-12. sınıfta öğrenim gören öğrencilerde madde kullanma durumunun incelenmesi amacıyla yapılmıştır.

Gereç ve Yöntemler: Araştırma, nüfusunun çoğunluğunu çocuk ve gençlerin oluşturduğu Şanlıurfa ilinde Ekim 2014-Mart 2015 tarihleri arasında tanımlayııı çalışma olarak yapılmışıı. Araşıımanın örneklemini, 7-12. sınıf 54,928 öğrenci oluşturmaktadır. Araştırmanın verileri literatür doğrultusunda araştırmacılar tarafindan hazırlanan anket formu ile elde edilmiş, anketler uygulanmadan önce bu konuda çalışmaları olan üç uzmandan görüş alınmıştır. Veriler SPSS 17 programında değerlendirilmiştir. Çalışmanın yapılabilmesi için kurumlardan yazılı, katılımcılardan sözlü izin alınmıştır.

Bulgular: Öğrencilerin \%51,6'sı erkek, \%23,8'i 9. sınıf öğrencisi, \%81,1'inin 4 ve daha fazla sayıda kardeşi bulunmakta, \%40,1'i ailedeki çocuk sırasında dördüncü ve daha fazla sırada yer almaktadır. Öğrencilerin \%23,2'si okul dışındaki zamanlarında bir işte çalışmaktadır. Öğrencilerin madde kullanma durumları incelendiğinde; \%6,3'ü sigara, \%2,4'ü sigara dışındaki diğer maddeleri kullandığını, \%13,1'içevresinde madde kullanan kişilerin olduğunu, \%31, '’ü merak nedeniyle, \%29,9'u kendini daha güçlü hissetmek için madde kullandığııı belirtmiștir. Erkek olanlarda, çalıșanlarda, baskııı bir aileye sahip olanlarda ve şiddete maruz kalanlarda sigara ve diğer maddeleri kullanma oranı yüksektir.

Sonuç: Bu çalışmada öğrencilerin madde kullanma durumuna yönelik elde edilen veriler doğrultusunda; madde kullanımının önlenmesine yönelik tüm öğrencileri kapsayacak düzeyde çalışmaların yapılması, ailelerde farkındalığın artırıması, ülke düzeyinde önleme politikalarının geliştirilmesi önerilmektedir. Anahtar Kelimeler: Adölesan, bağımılık, madde kullanımı 


\section{Introduction}

As old as the history of humanity, substance use is among the most important problems around the world. The 2012 World Drug Report determined that around 153.000300.000 people used illicit drugs (cannabis, opioids, cocaine, amphetamines, etc.) at a rate of 3.4-6.6\% in 2010 (1). It was indicated in the 2012 World Health Organisation data that approximately 3.3 million people die due to alcohol use each year. These deaths constitute $5.9 \%$ of all deaths in the world. Alcohol causes more than 200 kinds of diseases and injuries (2)

Adolescents are in the risk group for substance abuse. Trying or using substances in childhood or adolescence possesses a potential risk of developing substance abuse in adulthood (3). Substance abuse in adolescence affects the future life, brain development, socialisation processes of the adolescent in a negative way. It is also closely associated with other risky behaviours and getting involved in crime (3).

Numerous studies have been performed to determine substance abuse rates in Turkey and around the world (4). Few of the studies carried out in other cities to determine substance abuse rates in Turkey include data for Şanlıurfa. The city of Şanlıurfa has the third highest child population among the cities of south eastern Turkey (5). No studies have been conducted with a comprehensive number of samples for the adolescent population of Şanlıurfa. This study was performed to examine substance abuse and the factors that affect substance abuse by students in grades seven through twelve in Şanlıurfa. It was planned to initiate prevention studies by determining the causes of substance abuse such as geographical location, population composition, being a border city and risky schools.

\section{Materials and Methods}

This descriptive study was conducted between September 2014 and March 2015.

\section{The Research Sample}

The field of the study consists of 84.000 seventh and eighth graders in middle schools and ninth through twelfth graders in high schools under the Directorate of National Education in Şanlıurfa. This study aimed to reach all the seventh through twelfth graders in the city. The research sample consisted of 54.928 students who were at school on the day of data collection and agreed to participate in the study, which intended to include all the seventh through twelfth graders in all the middle and high schools in the city and counties. However, this could not be done as some schools did not give permission to conduct the study, or due to difficulties such as transportation. The participation rate was $65 \%$.

\section{Data Collection Materials}

The research data were obtained using a survey form prepared by the researchers after a review of the relevant literature. The opinions of specialists in this area were used to modify the survey form, and a pilot test was done with 15 students after this revision. The survey consisted of 50 questions; 22 were on substance abuse and 28 were about the factors that affect it and demographic information (gender, age, number of siblings, mother and father's age, education status, occupation, family's income status, etc). The adolescents and their teachers were informed about the study. It was explained to the entire sample group that only the volunteered would fill out the forms, and that their answers would remain confidential. They were asked to answer the questions after this step.

The surveys were administered in classrooms by pollsters and took 5-10 minutes to complete. The aim of the study was explained and information about the process was given. Questions about particular conditions participants might encounter during the study were answered beforehand. The children were assessed for the answers they gave to the questionnaire, and no laboratory tests were used to determine the presence of substance usage.

\section{The Ethical Aspects of the Research}

Written permissions from the institutions and the verbal consent of the participants were obtained for the study. This study was supported by Karacadağ Development Agency (project number: TRC2/14/DFD/0008). The ethical dimension of the study was embraced within the project evaluation process and the project was accepted.

\section{Statistical Analysis}

The data obtained from this research were evaluated using the SPSS 17. Averages, standard deviations, medians, minimum and maximum values, percentiles and chi-square were used to evaluate the data.

\section{Results}

Of the students who participated in the study, $46 \%$ were female, $51.6 \%$ were male, and $80.1 \%$ were older than 12 years of age. Of them, $23.8 \%$ were in ninth grade; $81.1 \%$ had 4 or more siblings, and $40.1 \%$ were fourth or more in sibling order. Of the participants, $64.3 \%$ said they were involved in social activities (music, sports, trips, cinema, etc.), and $84.9 \%$ claimed they loved their school while $23.2 \%$ said they worked in jobs to earn money.

The mothers of $47.8 \%$ of the students in the study were between 31 and 40 years of age; and $63.9 \%$ of the fathers were older than 40 . The mothers of $47 \%$ were illiterate while the fathers of $32.6 \%$ had completed primary education. The mothers of $91.6 \%$ were housewives. Of their fathers, $41.4 \%$ were self-employed. The monthly income of $39.6 \%$ was under 1,000 Turkish Liras. Of the students, $83.4 \%$ lived in nuclear families, and $55.4 \%$ said family decisions were made jointly. Exposure to domestic violence was claimed by $8.9 \%$.

Table I shows the data on substance abuse by the students. 
It was found that $6.3 \%$ of the students were using tobacco, and $2.4 \%$ were users of substances other than tobacco. Of them, $13.1 \%$ had substance abusers among their friends or in their family (Table I). Hashish and glue were used by $36.1 \%$, and $32.3 \%$ used bonsai among these. Propane was used by $15.5 \%$, and $10.5 \%$ drank alcohol. Finally, $5.5 \%$ claimed use of ecstasy. The age for starting smoking was under 10 for $40.7 \%$. Of them, $33.3 \%$ said they smoked more than one pack of cigarettes a day, $38.8 \%$ smoked due to boredom, and $36.6 \%$ started to smoke due to curiosity or to imitate their elders.

Of the substance users, $27 \%$ started before age 10, $31.3 \%$ said they began substance abuse out of curiosity, and $29.9 \%$ said they abused substances to feel better and more powerful. The percentage of students who had abused substances for seven years or more was $24.9 \%$. To obtain substances, $63.7 \%$ paid money and $28.3 \%$ got them from their friends for free.

Of the students, $31.4 \%$ said they abused substances once or twice a month, and $55.6 \%$ said they most often used substances at night. While $39.8 \%$ of the students wanted to quit substance abuse, $46.6 \%$ believed they could quit, and $26.5 \%$ were receiving support to quit. The percentage of students receiving support to quit from their friends only was $54.2 \%$.

Statistically significant differences were found between gender, work status, family type and domestic violence, and smoking and substance abuse by the students as seen in Table II $(p<0.01)$. Smoking and substance abuse rates were higher for male students, working students, children with extremely domineering families, and children exposed to domestic violence, and these findings are presented in Table II.

\section{Discussion}

The substance use rate among adolescents attending $7^{\text {th }}$ through $12^{\text {th }}$ grades in Şanlıurfa was found as $2.4 \%$ for substances and $6.3 \%$ for smoking (Table I). Lifetime substance use frequency was found to be $1.5 \%$ by "Research on the Prevalence of Substance Abuse in the Young Population" carried out by Turkish Monitoring Center for Drugs and Drug Addiction (TUBIM) in 2011 with 11.812 participants studying at general and technical high schools in 32 cities (4).

\begin{tabular}{|c|c|c|c|}
\hline \multicolumn{4}{|c|}{ Table I. Data distribution of substance use by students } \\
\hline \multicolumn{2}{|l|}{ Variable } & \multirow{2}{*}{\begin{tabular}{|l|}
$n^{*}$ \\
2984
\end{tabular}} & \multirow{2}{*}{$\begin{array}{l}\% \\
6.3\end{array}$} \\
\hline Smoking & Yes & & \\
\hline & No & 44485 & 81.0 \\
\hline \multirow[t]{2}{*}{ Use of substances (other than cigarettes) } & Yes & 858 & 2.4 \\
\hline & No & 34897 & 63.5 \\
\hline \multirow[t]{2}{*}{ Substance abuser Acquaintances } & Yes & 4347 & 13.1 \\
\hline & No & 28876 & 86.9 \\
\hline
\end{tabular}

Atilola et al. (3) studied alcohol and substance abuse by 2.454 adolescents in grades nine through twelve from seven developing countries: India, Serbia, Nigeria, Turkey, Indonesia, Croatia and Bulgaria. It was reported that $40.9 \%$ of the adolescents had used alcohol or substance at least once in the last year. The study's data for Turkey were collected in the city of Şanlıurfa, and the rate of adolescents abusing any substance was $24.3 \%$ during the previous 12 months. In the study of Atilola et al. (3); the sample group only consisted of high school students and the data were obtained via a measurement instrument aimed at determining the rate of using problematic substances. The rate of using problematic substances was determined as $12.9 \%$ (3). In our study, this rate was found to be lower, which is associated with the difference in the age group.

Ogel et al. (6) studied smoking, alcohol use and substance abuse with 11.989 primary school and 12.270 secondary school students in nine metropolises in 2004 . Of the primary school students, $16.1 \%$ said they had smoked at least once, $15.4 \%$ said they consumed alcohol, and $1.7 \%$ said they had used inhalants and drugs (6).

Tot et al. (7) studied smoking and the use of alcohol, hashish, inhalants and other illicit substances (heroin, cocaine, tranquillisers, etc.) in the last month and the factors that affect these forms of substance abuse with 3.282 sixth graders, tenth graders and college students in Mersin. The

\begin{tabular}{|c|c|c|c|c|}
\hline \multicolumn{5}{|c|}{ Table II. Variables that affect substance use } \\
\hline \multirow[t]{2}{*}{ Variables } & \multicolumn{2}{|c|}{ Smoking } & \multicolumn{2}{|c|}{ Substance use } \\
\hline & Yes (\%) & No (\%) & Yes (\%) & No (\%) \\
\hline \multicolumn{5}{|l|}{ Gender } \\
\hline Female & $645 \quad 2.9$ & 2173197.1 & $\begin{array}{ll}138 & 0.8\end{array}$ & 1695199.2 \\
\hline \multirow[t]{2}{*}{ Male } & 22609.4 & 2178590.6 & 6883.7 & 1791196.3 \\
\hline & \multicolumn{2}{|c|}{$X^{2}=8391 p<0.01$} & \multicolumn{2}{|c|}{$X^{2}=307.267 p<0.01$} \\
\hline \multicolumn{5}{|l|}{\begin{tabular}{|l|} 
Working status \\
\end{tabular}} \\
\hline Working & $637 \quad 16.0$ & $3346 \quad 5.2$ & 2036.4 & 297193.6 \\
\hline \multirow[t]{2}{*}{\begin{tabular}{|l|} 
Not working \\
\end{tabular}} & 187784.0 & 3428794.8 & 4941.8 & 2695897.2 \\
\hline & \multicolumn{2}{|c|}{$\mathrm{X}^{2}=711.611 \mathrm{p}<0.01$} & \multicolumn{2}{|c|}{$X^{2}=268.076 p<0.01$} \\
\hline \multicolumn{5}{|l|}{ Family feature } \\
\hline $\begin{array}{l}\text { Whatever my father } \\
\text { says is done }\end{array}$ & 14857.6 & 1652892.4 & 4382.8 & 1229197.2 \\
\hline $\begin{array}{l}\text { Extremely domineering } \\
\text { family }\end{array}$ & 126515.5 & 2559784.5 & 3358.0 & 1998492.0 \\
\hline \multirow[t]{2}{*}{$\begin{array}{l}\text { Decisions are made } \\
\text { jointly }\end{array}$} & $64 \quad 5.0$ & $457 \quad 95.0$ & 301.8 & $356 \quad 98.2$ \\
\hline & \multicolumn{2}{|c|}{$X^{2}=3.962 p<0.01$} & \multicolumn{2}{|c|}{$x^{2}=2.245 p<0.01$} \\
\hline \multicolumn{5}{|l|}{ Domestic violence } \\
\hline Yes & $764 \quad 18.2$ & $3425 \quad 81.8$ & 2968.7 & $3091 \quad 91.3$ \\
\hline \multirow[t]{2}{*}{ No } & 20014.9 & $38903 \quad 95.1$ & 4851.6 & 3015298.4 \\
\hline & \multicolumn{2}{|c|}{$X^{2}=5.179 p<0.01$} & \multicolumn{2}{|c|}{$X^{2}=6.969 p<0.01$} \\
\hline
\end{tabular}


highest rates of substance abuse were as 4.7\% smoking in the sixth grade, $25.3 \%$ smoking in the tenth grade, $43.9 \%$ using alcohol in college and $38.7 \%$ smoking in college $(7,8)$.

The substance abuse rates found by this study are similar to those of TUBIM in 2011. The substance abuse rates found by Atilola et al. (3) and Ogel et al. (6) were higher.

In the current study, $6.3 \%$ of students used cigarettes. Of the students who abused other substances, $36.1 \%$ used hashish and glue, and $32.3 \%$ abused bonsai. Of this group, $15.5 \%$ used propane, $10.5 \%$ used alcohol, and $5.5 \%$ used ecstasy. The smoking rate was higher than the rate for other substances in this study. The findings of this study are similar to those of Ogel et al. (6) and TUBIM (2011) (4).

In this study, hashish, glue and bonsai had the highest usage rate among substances other than cigarettes. In the study of European School Survey Project on Alcohol and Other Drugs carried out with 6.149 students around 15-16 years of age in Adana, Ankara, Diyarbakır, Istanbul, Izmir and Samsun in 2003, the lifetime rates were $5 \%$ inhalants, $4 \%$ hashish, 2\% ecstasy, 2\% heroin and $2 \%$ cocaine, and it was found that $5 \%$ had used hashish in the last year, and $3 \%$ in the last month (4).

Ogel et al. (6) indicated that $15.4 \%$ of the primary school students used alcohol and $1.7 \%$ used inhalants and drugs other than tobacco. They determined that $55.9 \%$ of the secondary school students smoked tobacco, and $45 \%$ used alcohol. However, only 4\% used cannabis, 5.1\% used inhalants, and $2.5 \%$ had used heroin or ecstasy at least once.

The TUBIM study (2011) found that $26.7 \%$ of the students had tried a tobacco product such as cigarettes, cigars, pipes or hookahs; $19.4 \%$ had tried alcoholic drinks, and $2.2 \%$ had used drugs due to illness (4).

The highest rates of substance abuse were reported as $37.8 \%$ for alcohol, $8.6 \%$ for hashish and $8.1 \%$ for other substances in a study by Atilola et al. (3). These data for Turkey were collected in the city of Şanlıurfa, and the rate of adolescents abusing any substance was reported as $24.3 \%, 19.3 \%$ for alcohol, $10 \%$ for hashish, $15.7 \%$ for other substances, and the rate of hazardous or impairing use was $12.9 \%$ (3). While alcohol use disorder and alcohol addiction were $7.5 \%$ in all European countries in the 2014 data of the World Health Organisation, these rates in Turkey were 2.7\% and $0.8 \%$ respectively. The use of alcohol rate was lower than that of most of the countries that participated in this study, and the rate of alcohol use was lower than most other substances. This can be attributed to the religious, cultural and geographical features of Şanlıurfa.

Studies by Corapçioglu and Ogel (8) with 18.556 tenth grade students in 1998 and 11.911 tenth grade students in 2001 showed the use of ecstasy rate as $2.65 \%$ in 1998 and $3.31 \%$ in $2001(6,7)$.

According to the 2012 World Drug Report, cannabis is the world's most widely used illicit substance. There are between 119 million and 224 million cannabis users worldwide, and consumption is stable. Hashish was identified as the most used substance in a study by Yüncü et al (9). Hashish was among the most used substances in this study, too. The results of this study are similar to those of Yüncü et al. (9).

Some sociodemographic features that affect smoking and substance abuse by students were also investigated in this study. The smoking and substance abuse rate was higher for male students, working students, children with extremely domineering families, and children exposed to domestic violence (Table II). The findings obtained from the study of Kokkevi et al. (10) on the variables affecting substance abuse by adolescents in six European countries were similar to the studies of TUBIM and Corapçioglu and Ogel (8). Substance abuse was more common among male students than female students.

The substance abuse rate was higher for working students than those who didn't work. This may be due to the fact that children escape parental control when they work, encounter dangers in the streets, engage in risky behaviours, and can easily obtain substances since they earn money.

Parents' educational levels, income levels, co-habitation, and substance abuse have been investigated in studies of families $(3,8,10)$. Regarding extremely domineering families and domestic violence, Kokkevi et al. (10) found that substance abuse was more common among adolescents who were unhappy in their relationship with their parents. When the family environment is unhealthy, the family bonds weaken, parental control of children is reduced, and children run away from home due to violence. The rate of the students who had more than four siblings and were fourth or more in sibling order, was $81.1 \%$. Substance abuse is related to high numbers of children in families in addition to parental variables. As a result of their study including 494 students (5, 7 and 9th grades), Trick et al. (11) determined that, the rate of using substances and other risky behaviours decreased as parents' follow-up increased.

In this study; $54.6 \%$ of adolescents stated that their parents had smoking habits, whereas $13.1 \%$ stated that they had acquaintances using substances other than cigarettes among their family members and/or friends. In the study of Lobato et al., (12) it was determined that the possibility of using substances was five times greater in adolescents that had histories of substance abuse in their family than those who did not, and eight times greater in individuals who had friends using substances. A number of studies suggest that the parents' substance use is an important risk factor upon the adolescents' substance use (13).

\section{Study Limitations}

Limitations of the study are as follows:

- Students at some schools did not participate in the study due to the failure of receiving institutional permission.

- Some questions in the questionnaire were not answered by all students.

- The research data were obtained using a survey form prepared by the researchers after a review of the relevant literature. The opinions of specialists in this area were used to modify the survey form, and a pilot test was done with 15 students after this revision. Because the purpose of the 
study was not to develop measuring tools to determine the use of the substances, no other tests were performed except for the expert opinions.

\section{Conclusion}

These data obtained on substance use by students and the factors that affect it suggest that studies should be carried out on substance use prevention, family awareness should be increased and prevention policies should be developed and implemented.

\section{Ethics}

Ethics Committee Approval: This study was supported by Karacadağ Development Agency (Project number: TRC2/14/ DFD/0008). Ethical dimension of the study was embraced within the project evaluation process and the project was accepted, Informed Consent: Consent form was filled out by all participants.

Peer-review: External and internal peer-reviewed.

\section{Authorship Contributions}

Surgical and Medical Practices: Hülya Karataş, Selma Kahraman, Concept: Hülya Karataş, Selma Kahraman, Design: Hülya Karataş, Selma Kahraman, Data Collection or Processing: Hülya Karataş, Selma Kahraman, Zeynep Marangoz, Analysis or Interpretation: Hülya Karataş, Selma Kahraman, Literature Search: Hülya Karataş, Writing: Hülya Karataş, Selma Kahraman.

Conflict of Interest: No conflict of interest was declared by the authors.

Financial Disclosure: This study was supported by Karacadağ Development Agency (Project number: TRC2/14/ DFD/0008).

\section{References}

1. World Drug Report 2012. http://www.unodc.org/documents/ data-and-analysis/WDR2012/WDR_2012_web_small.pdf. Erişim Tarihi: 17.08.2015.
2. World Health Organization. Global Status Report on Alcohol and Health 2014. http://www.who.int/substance_abuse/ publications/global_alcohol_report/msb_gsr_2014_1. pdf?ua=1. Erişim Tarihi: 17.08.2015.

3. Atilola O, Stevanovic D, Balhara YP, et al. Role of personel and family factors in alcohol and substance use among adolescents: an international study with focus on developing countries. J Psychiatr Ment Health Nurs 2014;21;609-17.

4. Turkey Drug Report 2014. http://www.kom.pol.tr Erişim Tarihi 18.08.2015.

5. Turkish Statistical Institute 2015. www.tuik.gov.tr Erişim Tarihi: 06.10.2015.

6. Ogel K, Corapçioğlu A, Sir A, et al. Tobacco, Alcohol and substance use prevalence among elementary and secondary school students in nine cities of Turkey. Turk Psikiyatri Derg 2004;15:112-8.

7. Tot S, Yazici K, Yazici A, Metin O, Bal N, Erdem P. Psychosocial correlates of substance use among adolescents in Mersin, Turkey. Public Health 2004;118:588-93.

8. Corapçioglu A, Ogel K. Factors associated with ecstasy use in Turkish students. Addiction 2004;99:67-76.

9. Yüncü Z, Saatçioğlu H, Aydın C, Özbaran NB, Altıntoprak E, Köse S. Urban Legend: Is the onset age in substance use decreasing? Literatür Sempozyum 2014;1:43-50.

10. Kokkevi A, Richardson C, Florescu S, Kuzman M, Stergar E. Psychosocial correlates of substance use in adolescence: a cross-national study in six European countries. Drug Alcohol Depend 2007;86:67-74.

11. Trick S, Jantzer $V$, Haffner J, Parzer P, Resch F. Parental monitoring and its relation to behaviour problems and risk behaviour in an adolescent school sample. Prax Kinderpsychol Kinderpsychiatr 2016;65:592-608.

12. Lobato $M$, Sanderman R, Pizarro E, Hagedoorn $M$. Marijuana use and dependence in Chilean adolescents and its association with family and peer marijuana use. Int J Behav Med 2016;24:144-52.

13. Durand SC, Fogger SA, McGuinness TM. Update on substance use in adolescence. J Psychosoc Nurs Ment Health Serv 2016;54:24-7. 


\section{Survey Form for $7^{\text {th }}-12^{\text {th }}$ Graders}
1. Gender:
Man ( )
Woman ( )

2. Age:

3. Grade:

4. Number of siblings?

5. What is your bird order among your siblings?

6. Mother's age:

7. Father's age:

8. Mother's education status:
a) Illiterate
b) Literate
c) Primary school graduate
d) Middle school
e) High school and above

9. Father's education status:
a) Illiterate
b) Literate
c) Primary school graduate
d) Middle school
e) High school and above

10. Mother's occupation:
a) Housewife-does not work
b) Officer
c) Worker
d) Freelancer
e) Other

11. Father's occupation:
a) Does not work
b) Officer
c) Worker
d) Freelancer
e) Other.

12. Family's income status:
a) Below $1000 \mathrm{TL}$
b) $1000 \mathrm{TL}$
c) Above $1000 \mathrm{TL}$

13. How is your family's monetary status?
a) Very good
b) Good
c) Medium
d) Bad
e) Very bad

14. With whom do you live together?
a) Parents-children
b) Mother or father, children
c) Father's father, grandfather, parents, children

d) Mother's mother, grandfather, parents, children e) Only mother's or father's mother, parents children f) Other

15. Home status:
() Rent
() Our own house( )
Other.

16. Which of the below defines your family?
a) Whatever my father says
b) Whatever my mother saysc) Common decisions are taken in the family
d) Whatever I say
e) I have a very oppressive family
f) Other.

17. Do you like coming to school?
a) Yes
b) $\mathrm{No}$

18. Are there days you skipped school?
a) Yes
b) No If yes, why?

19. Does your family give you allowance?
a) Yes
b) $\mathrm{No}$

20. How much allowance does your family give you weekly?

21. Was there any violence against you from your family?
a) Yes
b) $\mathrm{No}$

22. Who used violence?

23. If yes, how?

a) Beating/injuring

b) Swearing/insult

c) Sexual harassment

d) Other

24. If yes, how often?
a) Once a week
b) Once a month
c) Less than once a month
d) More than once a week 
25. Were there times you could not go home and had to spend the night outside?
a) Yes
b) No

26. If your answer is yes, can you explain the reason?
a) I work at night
b) I travel and have fun at night
c) I do not want to go home
d) I stayed with my friends e) Other......

27. Do you have any social activity?
a) Yes
b) $\mathrm{No}$

28. What kind of activities do you do?
a) Sports
b) Music
c) Reading
d) Travelling
e) Movies
f) Theater

29. What does "drug" bring into your mind?

30. Is there anyone smoking in your family?
a) Yes
b) No

31. Do you smoke?

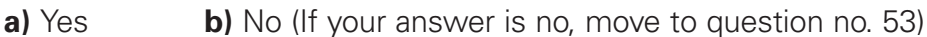

32. When did you start smoking?

33. Why did you start smoking?
a) Peer pressure
b) Saw it in my family
c) Curiosity
d) Aspiration
e) Boredom
f) Other

34. If yes, how often do you smoke?
a) Less than 1 package a day
b) More than 1 package a day
c) Other......

35. Have you used any drugs other than cigarettes?

a) Yes, I used

b) I did not (if your answer is no, move to question no. 51)

36. If yes; *Why did you start using that drug?
a) I was curious
b) To feel better
c) Because everybody was using it
d) My family/brother/etc. forced me
e) To do better
f) Because I was stressed g) Because I had problems
h) Because my friends asked me to
I) To look stronger
i) Other (please specify)

37. How do you acquire the drug you use?
a) My friends provide me for free
b) I purchase it
c) My relatives provide me for free
d) Other

38. Where do you think these drugs are sold the most?

39. Where do you think these drugs are used the most?

40. When did you start using drugs?

41. How long have you been using it?
a) Less than 1 year
b) 1-3 years
c) $4-6$ years
d) 7 years and above

42. How often do you use it?
a) More than once a day
b) Once a day
c) 1-2 times a week
d) 1-2 times a month
e) Other

43. How much do you use that drug?...

44. Which hours do you use that drug?

45. Does your family know that you use drugs?

$\begin{array}{ll}\text { a) Yes } & \text { b) } \mathrm{No}\end{array}$

46. Do you want to quit using that drug?
a) Yes
b) $\mathrm{No}$

47. If yes, did you ask help from anyone to quit it?
a) Yes
b) $\mathrm{No}$

48. If yes, ( ) from whom? No ()

49. Do you think you can quit using drugs?

$\begin{array}{ll}\text { a) Yes } & \text { b) } \mathrm{No}\end{array}$

50. Is there anyone from your friends or family using drugs?
a) Yes
b) No 